\title{
Analisa Kegagalan pada produk Replaceable Lip dan pengaruh deoksidasi Aluminium pada Baja Cor Tahan Panas SCH 22
}

\author{
Achmad Sambas ${ }^{1}$, Kus Hanaldi ${ }^{2}$, Ery Hidayat ${ }^{3}$ \\ ${ }^{1,2.3}$ Politeknik Manufaktur Negeri Bandung \\ 1,2,3 Jl. Kanayakan No 21 (Dago) Bandung \\ E-mail : sam@polman-bandung.ac.id
}

\begin{abstract}
Abstrak
Replaceable Lip merupakan salah satu komponen habis pakai dengan material Baja Cor Tahan Panas Stainless Steel (Heat Resistant Stainless Steel Casting) SCH 22. Produk tersebut dibuat di Polman khususnya di Jurusan Teknik Pengecoran Logam, namun masih ada kendala dalam proses pembuatannya. Masalah yang terjadi pada Replaceable lip ini adalah adanya cacat coran berupa porositas atau inklusi dibawah permukaan tuangan. Cacat tersebut dapat diketahui dari permukaan luarnya setelah dilakukan proses permesinan. Umumnya, porositas dalam produk coran disebabkan oleh gas yang terjebak atau akibat dari penyusutan cairan ketika membeku. Selama ini porositas dicegah dengan proses degassing konvensional dengan Aluminium, tetapi belum memberikan hasil yang optimal. Penelitian ini bertujuan untuk menganalisa dan mengatasi kegagalan/ cacat cor yang terjadi pada produk cor Replaceable lip serta mengembangkan material Baja Cor Tahan Panas SCH22 terhadap kualitas produk yang bebas porositas. Manfaat dari penelitian yaitu tercapainya optimalisasi proses degasing dalam penyelesaian masalah cacat, dan prototip produk yang dapat digunakan secara langsung bagi industri pengguna. Metode yang akan dilakukan yaitu dengan membuat spesimen berupa sampel uji dan sampel produk dengan proses pengecoran logam, kontrol parameter proses metalurgi dengan variasi degasing Al dari 0,1\% sd 0,4\%, dan Temperatur cor yang tetap sekitar 1450 sd $1550^{\circ} \mathrm{C}$. Dari kedua sampel dilakukan pengamatan terhadap porositas, kekuatan mekanik dan struktur mikro, untuk melihat pengaruh dari degasing Aluminium.
\end{abstract}

Kata Kunci: cacat cor, Replaceable Lip, Heat Resistant, aluminium degasing

\section{PENDAHULUAN}

Material SCH 22 merupakan kelompok Baja Cor Tahan Panas Stainless Steel (Heat Resistant Stainless Steel Casting ) yang umumnya diaplikasikan pada kondisi temperatur kerja antara 650 hingga $1315^{\circ} \mathrm{C}$. Material tersebut dipilih dikarenakan ketahanan terhadap korosi, stabil pada temperatur tinggi, dan tahan terhadap creep (pemuluran/ retak akibat panas).

Aplikasi material tersebut cukup luas pada komponen-komponen tahan panas di industri pengolahan semen, industri pupuk, industri minyak/ gas dan pada industri oven pemanas. Kebutuhan suplai produk yang menggunakan kandungan lokal dari komponen tersebut, mendorong dilakukannya pengembangan material ini dari aspek kualitas dan kuantitasnya.

Replaceable lip merupakan salah satu komponen habis pakai pada mesin pengolah semen. Produk tersebut dibuat di Polman khususnya di Jurusan
Teknik Pengecoran Logam. Namun dalam proses pengolahannya masih ada kendala. Masalah yang terjadi pada Replaceable lip ini adalah adanya cacat coran berupa porositas atau inklusi dibawah permukaan tuangan. Cacat - cacat tersebut dapat diketahui dari permukaan luarnya setelah dilakukan proses pemesinan.

Perumusan masalah, umumnya porositas dalam produk coran disebabkan oleh gas larut dan terjebak, atau feeding yang kurang. Selama ini porositas dicegah dengan proses degassing konvensional dengan pemberian Aluminium, tetapi belum memberikan hasil yang optimal. Jumlah penggunaan degassing Aluminium yang optimal dan pengaruhnya pada material, sampai sekarang belum pernah dilakukan dan diteliti oleh praktisi dan ilmuwan skala nasional.

Menurut Wahyono Suprapto (2011); dari Kalpakjian dan Schmid, Jorstad dan Rasmussen, apabila porositas berbentuk bulat (spherical), dindingnya halus dengan lubang-lubang mengkilap, 
dan porositasnya tersebar diseluruh produk coran, umumnya porositas tersebut disebabkan oleh gas yang terjebak (hidrogen). Tetapi jika dindingnya kasar dan bersudut, porositas berasal dari shrinkage diantara dendrit. Gas terlarut dapat dihilangkan dari logam melt dengan flushing, atau dibersihkan dengan gas inert atau dengan peleburan dan solidifikasi vakum. Jika gas terlarut oksigen, logam meltnya dioksidasi. Deoxidizer baja menggunakan; aluminium, silicon.

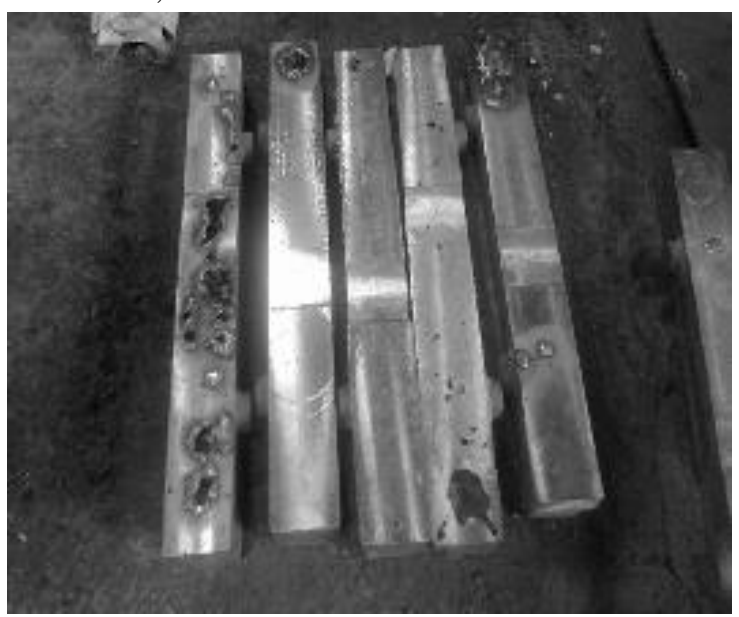

Gambar 1. Cacat coran yang terlihat setelah dilakukan proses pemesinan

Jenis material mengacu pada contoh produk aslinya yaitu baja tahan karat type SCH 22 memiliki kandungan Karbon $<0,45 \%$. Kandungan Karbon yang rendah memungkinkan terjadinya oksidasi pada cairan logam. Bentuk fisik dari oksidasi ini terlihat pada permukaan yang telah diproses pemesinan, berupa lubang-lubang kecil. Dari aspek perancangan coran, hal tersebut terjadi karena disain tuangan yang belum optimal. Beberapa alternatif yang dapat dilakukan seperti ; penentuan lay out penambah dan perhitungan ukuran penambah perlu dikaji kembali

Tujuan dari penelitian yaitu menganalisa penyebab cacat cor, menghilangkan porositas pada material Baja Cor Tahan Panas SCH 22 dengan proses "deoksidasi/ degasing Aluminium, serta melihat pengaruh bahan deoksidasi degasing Aluminium terhadap sifat Mekanik Baja Cor Tahan Panas SCH 22.

Manfaat setelah pengembangan yaitu hasil dari penelitian yaitu tercapainya optimalisasi proses degasing dalam penyelesaian masalah cacat, dan prototip produk dengan material Baja Cor Tahan Panas SCH 22 yang memiliki kualitas baik, terbebas dari porositas (soundcasting) yang dapat digunakan secara langsung bagi industri pengguna. Sehingga industri pengecoran nasional dapat membuat produk serupa dengan kualitas yang tidak kalah dengan produk impor.

\section{METODE}

Langkah dimulai dari analisa cacat cor untuk memastikan bahwa cacat yang terjadi akibat dari porositas gas, kemudian menelusuri penyebab dan memformulasikan cara perbaikannya. Analisa cacat mengacu pada literatur "AFS Analysis of CAsting Defect". Berikutnya melakukan perancangan proses pengecoran untuk mendapatkan sampel uji dan prototip produk jadi, melalui pembuatan pola, pembuatan cetakan, peramuan material dan dilanjutkan dengan proses deoksidasi dengan memvariasikan jumlah Aluminium dari $0,1 \%$ hingga $0,4 \%$. Jumlah Alumium yang diberikan berdasarkan prosentasi berat cairan. Sedangkan target Alumium yang terlarut dalam cairan adalah sesuai dengan kurva yang ditunjukkan pada Gambar 2. Gambar 2. menujukkan kesetimbangan antara Aluminium dan Oksigen. Dari gambar tersebut dapat diketahui bahwa dengan menambahkan aluminium, kadar oksigen akan menurun dan dari hasil reaksi tersebut akan membentuk $\mathrm{A} 12 \mathrm{O} 3$.

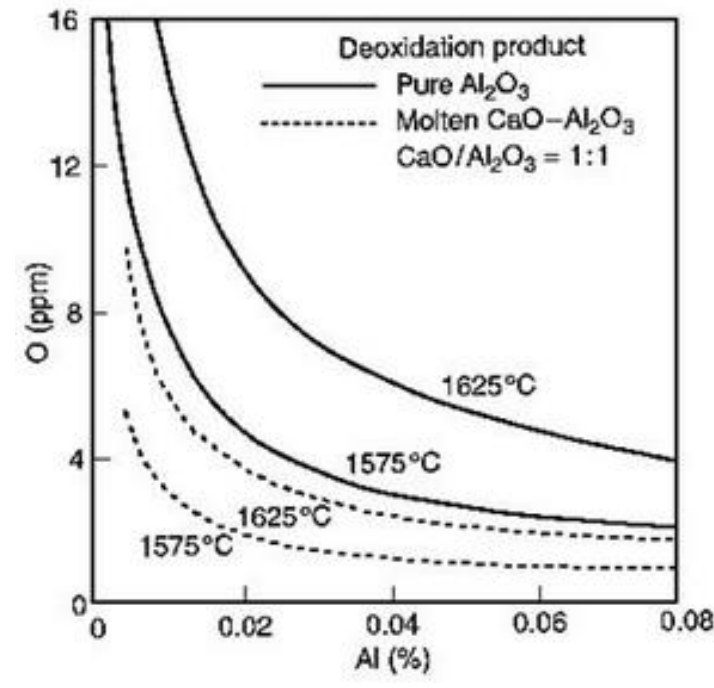

Gambar 2. Kurva kesetimbangan Alumium Oksid.

Gambar 3. menunjukkan skema proses pembuatan sampel uji dengan variasi deoksidasi Aluminium.

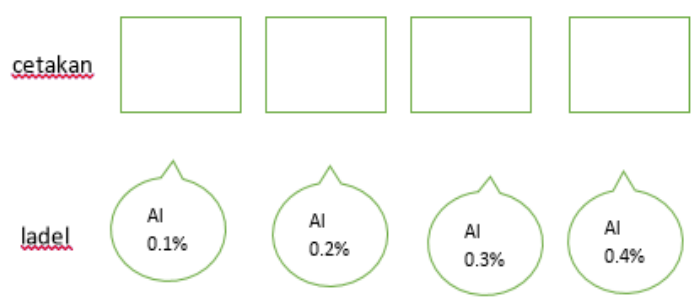

Gambar 3. Skema penuangan cetakan 
Dilakukan preparasi sampel uji untuk melihat porositas dan karakterisasi material melalui pengujian tarik, kekerasan dan struktur mikro. Output dari karakterisasi dapat dilihat pada matrix percobaan yang ditunjukkan pada Tabel 2 .

Tabel 2. Matrix rancangan percobaan

\begin{tabular}{|c|c|c|c|}
\hline $\begin{array}{c}\text { Jumlah } \\
\text { degassing } \\
\text { Al }\end{array}$ & $\begin{array}{c}\text { Kekuatan } \\
\text { tarik }\end{array}$ & $\begin{array}{c}\text { Nilai } \\
\text { Kekerasan }\end{array}$ & $\begin{array}{c}\text { Struktur } \\
\text { mikro }\end{array}$ \\
\hline $0,1 \%$ & Data & Data & Image \\
\hline $0,2 \%$ & Data & Data & Image \\
\hline $0,3 \%$ & Data & Data & Image \\
\hline $0,4 \%$ & Data & Data & image \\
\hline
\end{tabular}

Pengujian kekuatan tarik menggunakan mesin uji tarik universal dan pengujian kekerasan menggunakan metoda pengujian kekerasan Brinnell, sedangkan untuk anaisa struktur mikro menggunakan perbesaran gambar dengan mikroskop optik dengan perbesaran 100 kali.

\section{HASIL DAN PEMBAHASAN}

Analisa cacat cor

Pada tahap ini, metodologi yang digunakan adalah menganalisa cacat cor (AFS analysis of casting defect), agar diketahui ciri, jenis dan penyebab cacat serta cara penanggulangannya

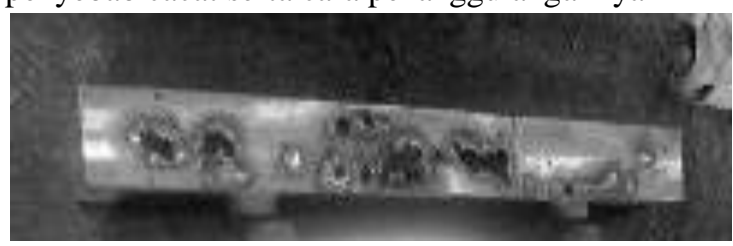

Gambar 3. Cacat yang terjadi pada produk Replaceable Lip

Mengidentifikasi Kegagalan Cacat Cor pada produk "Replacable lip", dengan langkah sebagai berikut:

- Mengamati bentuk/ morfologis cacat cor

- Membandingkan cacat cor sejenis yang kemungkin -an bisa terjadi berikut cirinya

- Merumuskan jenis cacat cor yang terjadi pada produk "Replacable lip",
Tabel 2. Perbandingan Cacat Cor.

\begin{tabular}{|l|}
\hline Nama Cacat dan Ciri \\
\hline INKLUSI TERAK \\
- Bentuk tidak \\
beraturan \\
Permukaan tidak \\
halus
\end{tabular}

Ciri cacat yang terjadi pada produk replaceable, kemudian dibandingkan dengan cacat cor sejenis yang mungkin terjadi (dari referensi). Tabel 2. menunjukkan jenis dan ciri cacat yang memungkinkan terjadi di daerah permukaan atas produk cor

Dari ciri yang terjadi, jenis cacat cor pada produk "Replacable tip" merupakan POROSITAS GAS.

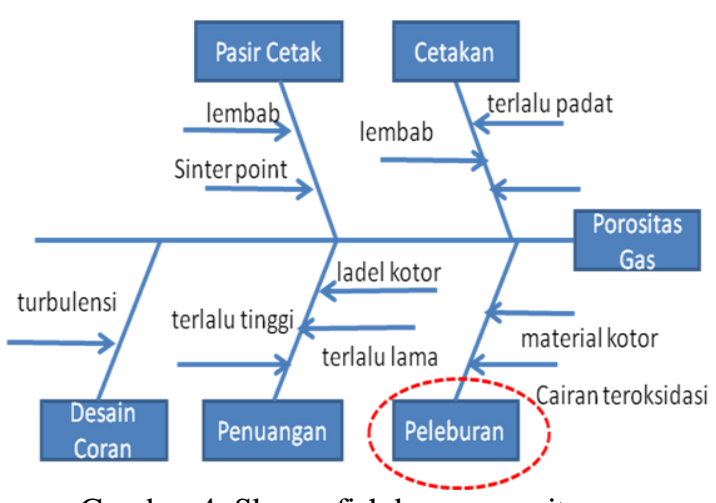

Gambar 4. Skema fish bone porositas gas 
Setelah diketahui jenis cacat, langkah selanjutnya adalah mencari penyebab cacat, dengan skema fish bone. Gambar 4. menunjukkan parameter yang dapat menyebabkan porositas pada produk cor. Dari beberapa parameter tersebut, dipilih parameter peleburan yang menjadi fokus pada penanggulangan kegagalan Cacat Cor Porositas Gas. Cacat porositas tersebut berasal dari proses peleburan, yang mana cairan logam mengalami oksidasi sehingga di dalam cairan logam tersebut terbentuk gelembung gas. Gas tersebut akibat dari ikatan antara Oksigen dengan unsur yang berada dalam logam. Untuk mencegah Oksigen berikatan dengan unsur yang berada dalam logam, maka diberikan unsur yang lebih reaktif terhadap Oksigen, yaitu Aluminium atau Silikon.

\section{Hasil Proses Pengecoran}

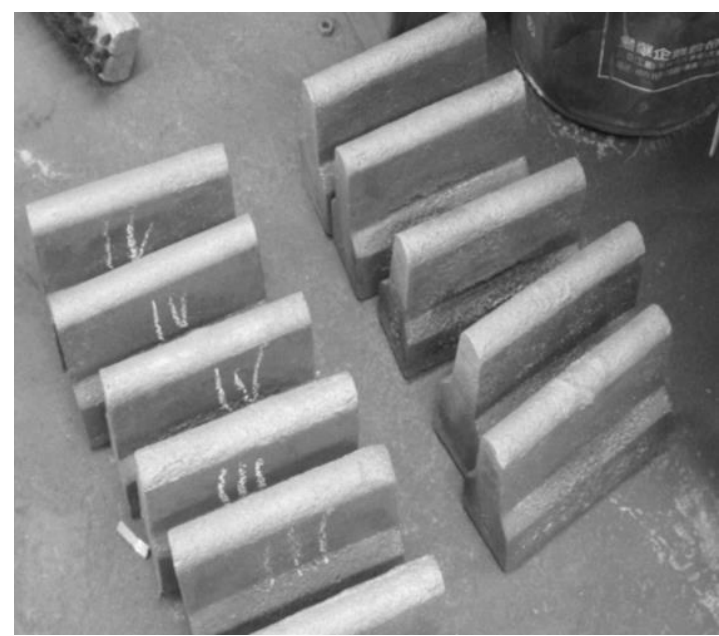

Gambar 5. Prototip Y-blok

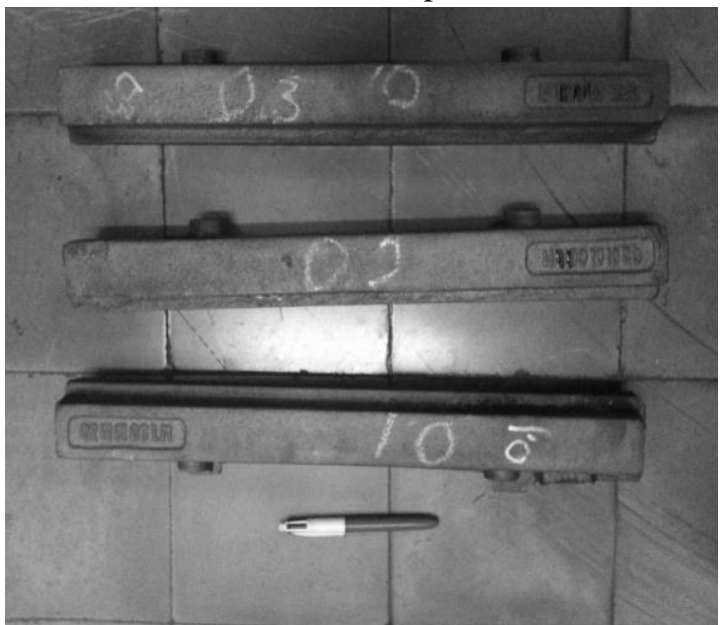

Gambar 6. Prototip "Produk Replaceable

Proses pengecoran logam menghasilkan prototip produk replaceable lip 3 buah dan Y-blok benda uji 12 buah. Gambar 5. dan Gambar 6. menunjukkan produk hasil proses pengecoran, berupa sampel uji Y blok dan prototip produk replaceable.

\section{Hasil Pemotongan sampel uji Y-blok}

Pemotongan dilakukan pada bagian ujung dari Yblok secara memanjang. Gambar 7. menunjukkan posisi pemotongan pada sampel uji Y-blok. Hasil potongan diamati secara visual, untuk melihat porositas yang terjadi. Nampak permukaan hasil pemotongan begitu mengkilat dan kokoh, terlihat bahwa material tersebut merupakan material yang ulet. Terbukti ketika di potong, memang agak sulit.

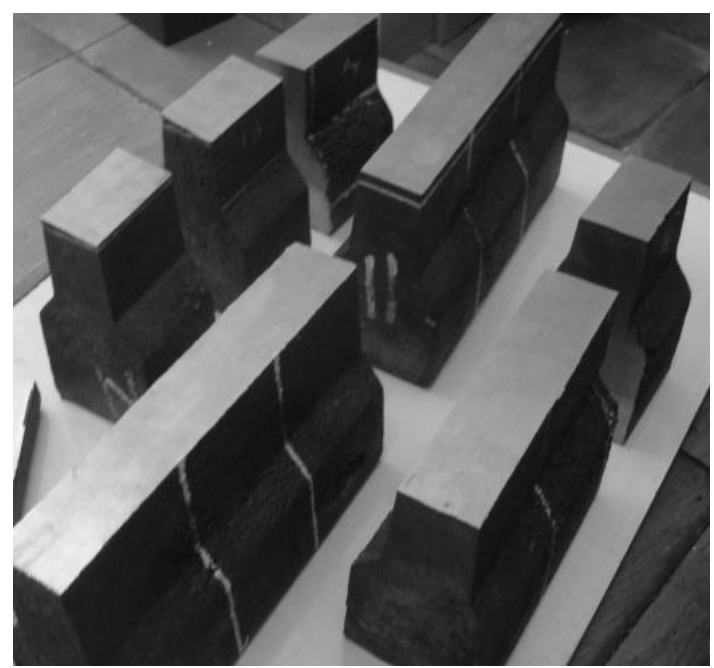

Gambar 7. Bagian potongan pada sampel uji Y-blok

Gambar 8, 9, 10 dan 11 menunjukkan hasil pengamatan visual penampang potong pada sampel uji Y-blok dengan variasi bahan deoksidasi Aluminium dari $0,1 \%$ hingga $0,4 \%$.

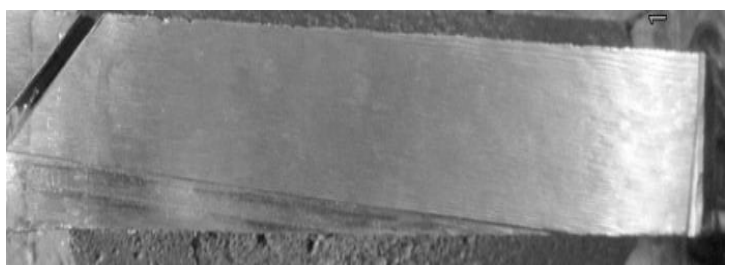

Gambar 8. Penampang potong pada sampel uji Yblok dengan deoksidasi $0,1 \% \mathrm{Al}$

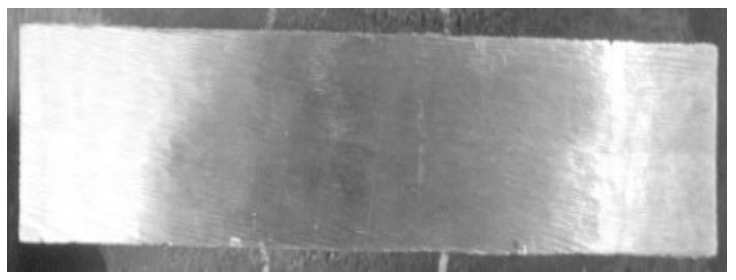

Gambar 9. Penampang potong pada sampel uji Yblok dengan deoksidasi $0,2 \% \mathrm{Al}$ 


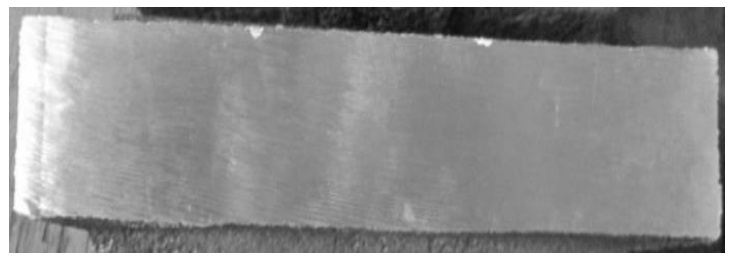

Gambar 10. Penampang potong pada sampel uji Yblok dengan deoksidasi $0,3 \% \mathrm{Al}$

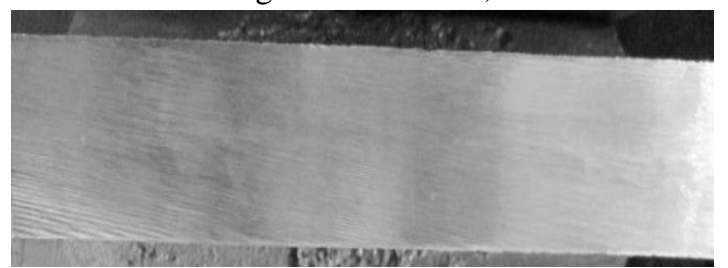

Gambar 11. Penampang potong pada sampel uji Yblok dengan deoksidasi $0,4 \% \mathrm{Al}$

Dari ke empat hasil pengamatan visual penampang potong pada sampel uji Y-blok, tidak ada porositas yang terjadi. Menunjukkan bahwa proses deoksidasi dengan Aluminium dapat menghilangkan porositas. Gas Oksigen yang terdapat dalam cairan, dapat terikat dengan sempurna oleh bahan deoksidasi Aluminium.

\section{Hasil Pemotongan pada Replaceable}

Bagian permukaan prototip produk replaceable yang telah dilakukan proses pemesinan dapat dilihat pada gambar 12, 13 dan 14. Gambar tersebut merupakan penampang hasil proses pemesinan. Pemotongan dilakukan sedalam $2 \mathrm{~mm}$. Dari ketiga prototip tersebut diamati secara visual

Gambar 12. menunjukkan gambar hasil pengamatan visual penampang potong pada prototip replaceable lip, hasil deoksidasi $0,1 \%$ Aluminium. Tidak ada porositas yang terjadi. Menunjukkan bahwa proses deoksidasi dengan Aluminium dapat menghilangkan porositas. Gas Oksigen yang terdapat dalam cairan, dapat terikat dengan sempurna oleh bahan deoksidasi Aluminium.

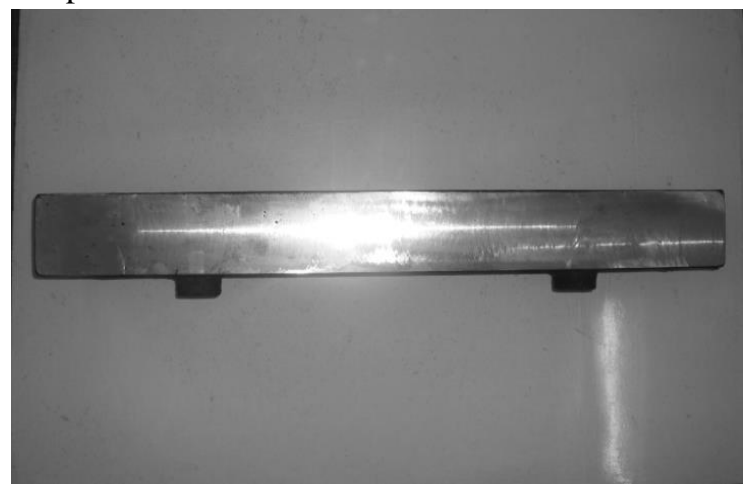

Gambar 12. Penampang potong pada Prototip “replaceable lip" dengan deoksidasi 0,1\% Al
Gambar 13. menunjukkan gambar hasil pengamatan visual penampang potong pada prototip replaceable lip, hasil deoksidasi $0,2 \%$ Aluminium. Terdapat sedikit porositas yang terjadi. Menunjukkan bahwa proses deoksidasi dengan Aluminium dapat menghilangkan porositas, gas Oksigen yang terdapat dalam cairan, dapat terikat dengan sempurna oleh bahan deoksidasi Aluminium. Porositas yang terjadi merupakan residu hasil reaksi degasing menjadi terak

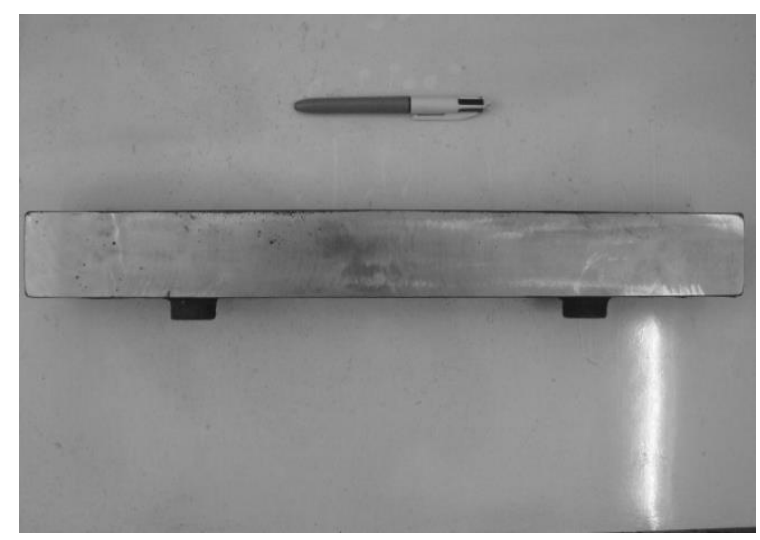

Gambar 13. Penampang potong pada Prototip "replaceable lip" dengan deoksidasi 0,2\% Al

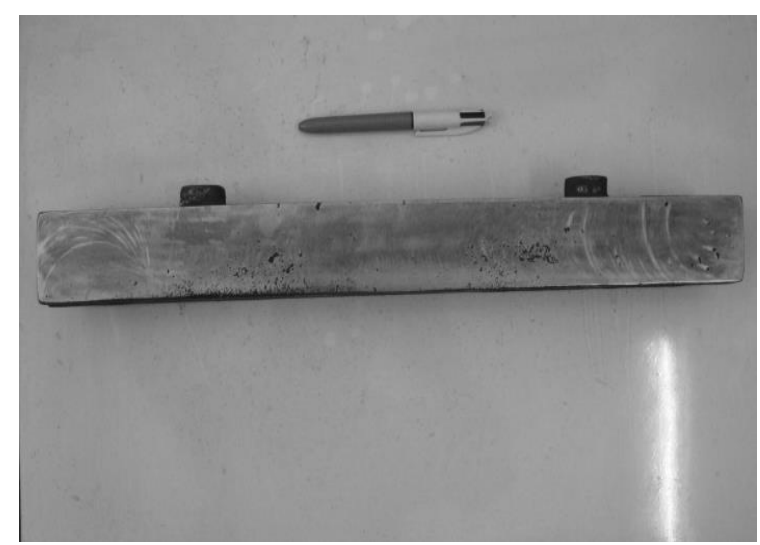

Gambar 14. Penampang potong pada Prototip "replaceable lip" dengan deoksidasi 0,3\% Al

Gambar 14. menunjukkan gambar hasil pengamatan visual penampang potong pada prototip replaceable lip, hasil deoksidasi 0,3\% Aluminium. Porositas yang terjadi semakin banyak, namun porositas tersebut merupakan inklusi yang terjadi akibat hasil reaksi antara ikatan Oksigen dengan Aluminium menjadi Aluminium Oksid berupa terak. Reaksi yang terjadi adalah sbb:

$$
\frac{4}{3} \mathrm{Al}+\mathrm{O}_{2} \rightarrow \frac{2}{3} \mathrm{Al}_{2} \mathrm{O}_{3}
$$


Dari diagram kesetimbangan Deoksidasi Al, disebutkan bahwa, dengan adanya elemen Aluminium sebanyak $0,1 \%$ pada cairan baja, akan menurunkan jumlah Oksigen hingga 1ppm. Terbukti dengan semakin banyaknya elemen Aluminium, akan menghasilkan residu berupa terak.

\section{Hasil Karakterisasi Material}

Proses pengujian tarik dilakukan berdasarkan standar JIS Z 2201. Spesimen uji Tarik dibuat melalui proses pemesinan yaitu pembubutan. Dari beberapa kali pengujian yang telah dilakukan didapatkan data sebagai berikut.

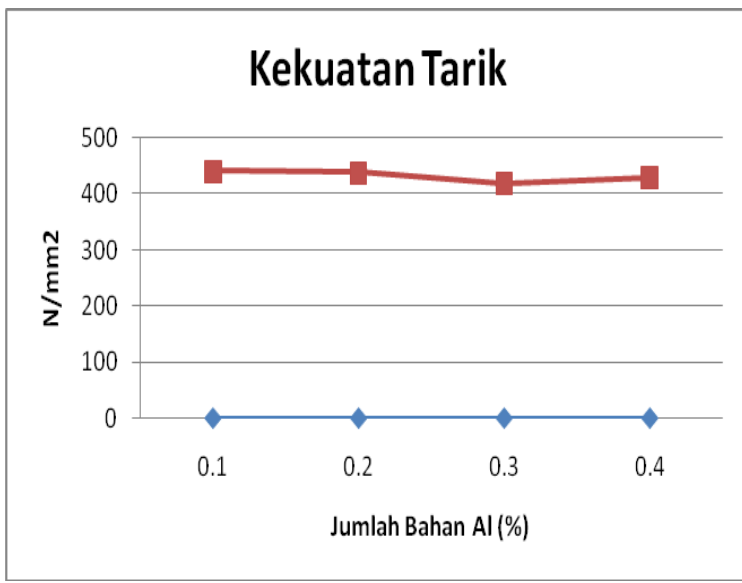

Gambar 15. Kurva uji tarik

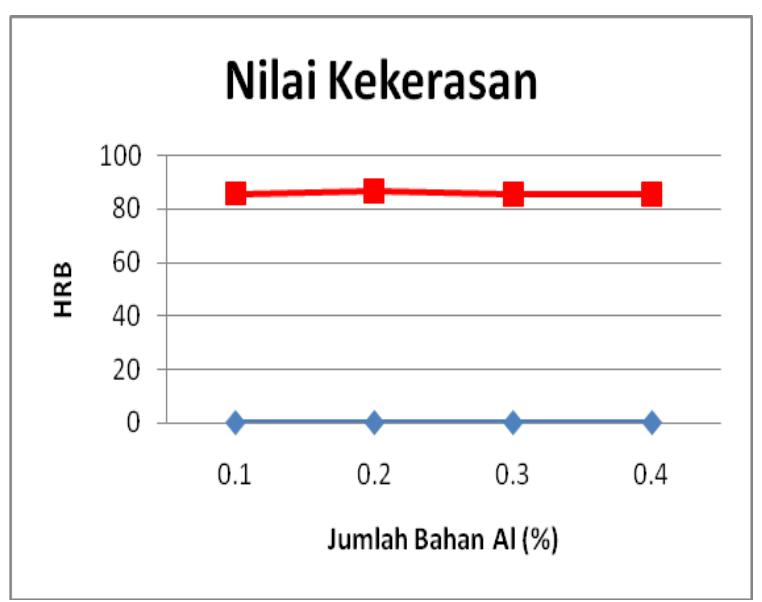

Gambar 16. Kurva uji kekerasan

Kurva diatas merupakan hasil pengujian tarik dan hasil pengujian kekerasan. Gambar 15. menunjukkan kurva hasil pengujian tarik. Pengujian tarik dilakukan sebanyak dua belas kali. variasi aluminium $0.1 \%$ hingga $0.4 \%$, tiap variasi sampel uji tarik yang dibuat adalah tiga buah. Kuat tarik tertinggi berada pada jumlah Aluminium sebesar $0.1 \%$ dengan nilai kekuatan tarik sebesar 430 $\mathrm{N} / \mathrm{mm} 2$ dan terendah berada pada jumlah
Aluminium sebesar $0.3 \%$ dengan nilai kekuatan tarik sebesar $420 \mathrm{~N} / \mathrm{mm} 2$. Dari kurva diatas dapat dilihat bahwa pengaruh Aluminium pada proses deoksidasi terhadap sifat mekanik tidak terlihat signifikan. Hal ini ditunjukkan dengan nilai hasil uji tarik tidak mengalami perubahan secara linier seiring dengan meningkatnya persentase pembubuhan Aluminum ke dalam cairan.

Gambar 16. menunjukkan kurva hasil pengujian kekerasan. Pengujian kekerasan yang dilakukan menggunakan metode kekerasan Rockwell skala B dengan nilai kekerasan HRB, indenter yang digunakan menggunakan bola dengan diameter 1/16 inci. Benda uji yang digunakan untuk kekerasan Rockwell B diambil dari spesimen uji tarik yatu pada bagian spesimen yang dicekam. Pengujian kekerasan dilakukan pada empat sampel uji yaitu berdasarkan variasi deoksidasi aluminium $0.1 \%$ hingga $0.4 \%$. Nilai kekerasan yang dihasilkan berkisar di angka 83 HRB. Nilai kekerasan yang dihasilkan tidak berbeda jauh antara yang satu dengan yang lainya. Hasil pengujian kekerasan ini semakin memperkuat bukti bahwa, pengaruh pembubuhan unsur Aluminum ke dalam cairan logam terhadap sifat mekanik tidak signifikan, sejalan dengan apa yang telah dipaparkan pada hasil uji tarik.

Pengujian struktur mikro dilakukan untuk mengetahui konfigurasi fasa yang terjadi. Proses dimulai dengan pengampelasan spesimen secara bertahap (dari ukuran amplas 120 hingga 1000 mesh). Setelah halus dilakukan polishing, kemudian etsa dilakukan dengan jenis etsa vilella dengan waktu pengetsaan sekitar 18 menit, alat uji yang digunakan adalah mikroskop optik dengan perbesaran 100x. Pengamatan struktur mikro dilakukan sebanyak empat buah berdasarkan variasi deoksidasi aluminium $0.1 \%$ hingga $0.4 \%$

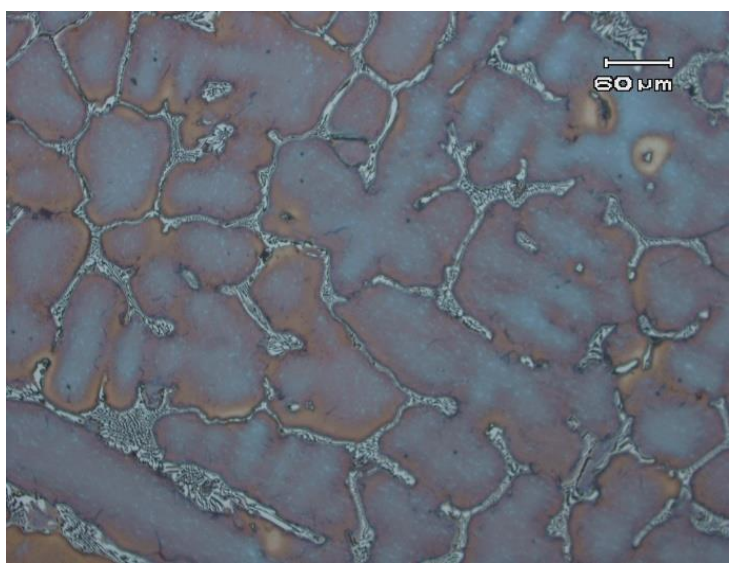

Gambar 17. Penampang potong pada sampel uji Yblok dengan deoksidasi 0,1\% Al, Austenite $71 \%$, Karbida krom $29 \%$ 


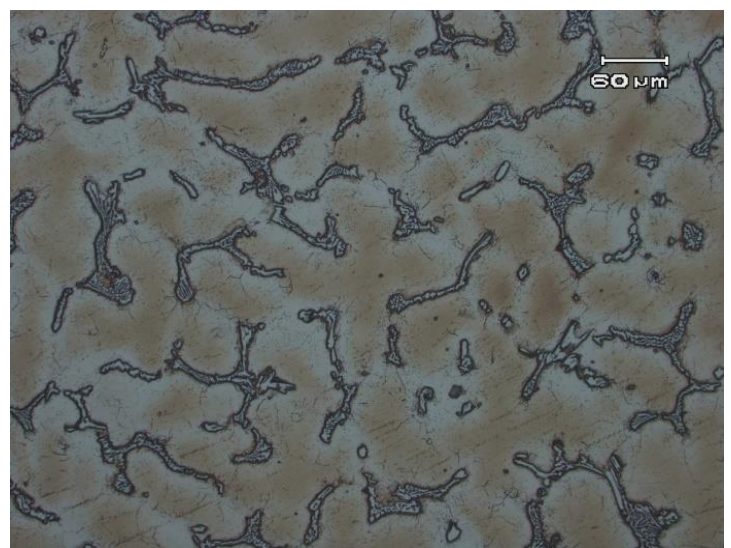

Gambar 18. Penampang potong pada sampel uji Yblok dengan deoksidasi 0,2 \% Al, Austenite71\%, Karbida krom $29 \%$

Gambar 17. menunjukkan gambar struktur mikro material SCH 22 (heat resistant stainless steel) hasil deoksidasi dengan Aluminium sebanyak 0,1\%. Nampak struktur yang terbentuk adalah fasa Austenit dan karbida krom sebagai batas butir. Jumlah fasa Austenit sebesar $71 \%$ dan karbida krom sebesar 29\%. sifat dari austenit adalah lunak, sedangkan karbida krom adalah keras. Karena struktur material ini didominasi oleh fasa Austenit yang lunak, maka nilai kekerasan yang dihasilkan menunjukkan angka yang rendah yaitu 83 HRB.

Gambar 18. menunjukkan gambar struktur mikro material SCH 22 (heat resistant stainless steel) hasil deoksidasi dengan Aluminium sebanyak 0,2\%. Nampak struktur yang terbentuk adalah fasa Austenit dan karbida krom sebagai batas butir. Jumlah fasa Austenit sebesar $71 \%$ dan karbida krom sebesar $29 \%$.

Dari kedua gambar struktur mikro diatas, tidak ada perubahan secara signifikan. Jumlah fasa Austenit dan karbida krom tetap, yang agak berubah adalah konfigurasi lengan karbida krom yang memendek. Artinya pemberian Alumunium hingga $0,2 \%$ tidak terlalu berpengaruh terhadap struktur mikro material SCH 22 (heat resistant stainless steel).

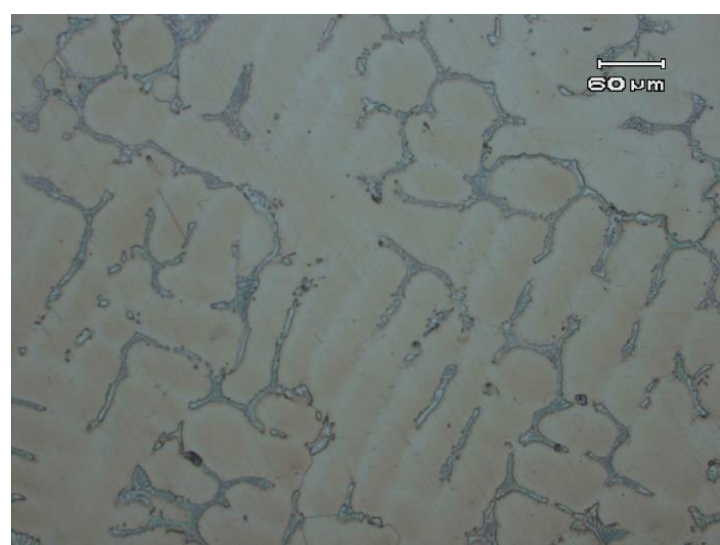

Gambar 19. Penampang potong pada sampel uji Yblok dengan deoksidasi 0,3\%. Austenite $72 \%$.

Karbida krom $28 \%$

Gambar 19. menunjukkan gambar struktur mikro material SCH 22 (heat resistant stainless steel) hasil deoksidasi dengan Aluminium sebanyak 0,3\%. Nampak struktur yang terbentuk adalah fasa Austenit dan karbida krom sebagai batas butir. Jumlah fasa Austenit sebesar 72\% dan karbida krom sebesar 28\%. konfigurasi karbida krom lebih mirip dengan gambar 17.

Gambar 20. menunjukkan gambar struktur mikro material SCH 22 (heat resistant stainless steel) hasil deoksidasi dengan Aluminium sebanyak 0,4\%. Nampak struktur yang terbentuk adalah fasa Austenit dan karbida krom sebagai batas butir. Jumlah fasa Austenit sebesar $71 \%$ dan karbida krom sebesar $29 \%$.

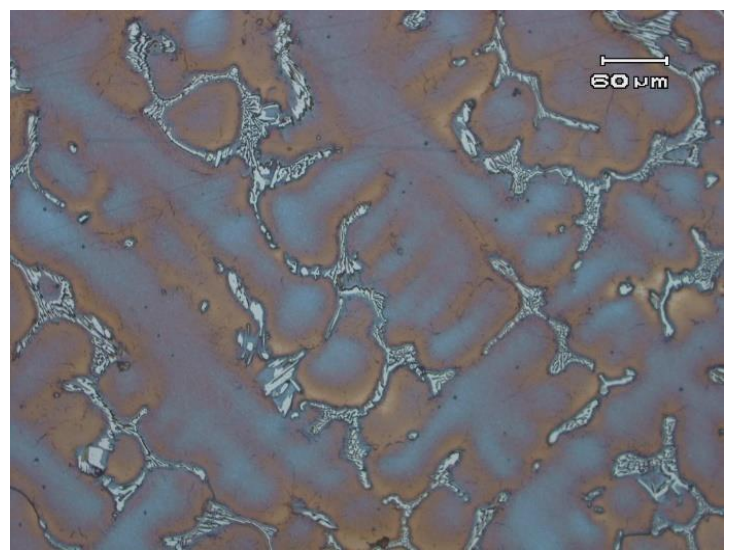

Gambar 20. Penampang potong pada sampel uji Yblok dengan deoksidasi 0,4\%. Austenite71\%, Karbida krom $29 \%$

Dari keempat gambar struktur mikro, fasa yang ada yaitu austenit dan karbida krom. Berdasarkan perbandingan jumlah fasa yang telah diukur pada setiap sampel uji, menunjukkan nilai persentase fasa austenit dan karbida krom dengan rentang nilai 
pendek. Rata-rata terdapat $71 \%$ fasa Austenit dan 29\% Karbida krom.

Dari pengamatan struktur mikro dapat dilihat bahwa, adanya unsur Aluminium dalam material baja tahan panas SCH 22 tersebut tidak begitu signifikan mengubah jumlah fasa austenit dan karbida krom. Terdapat perubahan yang agak menonjol pada hasil deoksidasi dengan menggunakan 0,4\% Aluminium. Morfologis karbida krom agak melebar, namun secara prosentase tidak terlalu signifikan. Artinya dengan persentase pembubuhan aluminum dari $0.1 \%$ hingga $0.4 \%$ tidak mempengaruhi pembentukan struktur mikro.

\section{KESIMPULAN}

Proses "deoksidasi Al", dapat menghilangkan porositas pada material Baja Cor Tahan Panas SCH 22. Penggunaan jumlah deoksidasi yang optimal adalah $0,1 \%$. Diperoleh prototip produk Replaceable lip yang terbebas dari porositas.

Proses deoksidasi Al hingga 0,4\%, tidak berpengaruh terhadap sifat Mekanik Baja Cor Tahan Panas SCH22.

Proses deoksidasi Al hingga 0,4\%, tidak berpengaruh terhadap struktur miro Baja Cor Tahan Panas SCH22.

\section{DAFTAR PUSTAKA}

[1] American Foundryman Society (1974); Analysis of Casting Defect.

[2] Aziz Abdul, Bambang Suharno (2007), "Karakterisasi Kekuatan Tarik dan Struktur Mikro Baja Cor Tahan Panas HK 40 Berbahan Baku Ferro Nikel Lokal", Seminar Nasional Metalurgi dan Material (SENAMM) 12007 Universitas Indonesia

[3] Beeley, P (2001). Foundry Technology, Butterworth Heineman, Oxford

[4] Davis, J.R (1997); ASM Speciality Handbook: Heat Resistant Material ASM Handbook.

[5] Heine Richard W. (1967), Principles of Metal Casting, Mc Graw Hills.

[6] Muhamad Daud Pinem. (2005) Jurnal Teknik SIMETRIKA Vol. 4 No. 1 - April 2005: p. $301-306$,

[7] Rolf Roller.(1986), Grund-Und Fachkenntnisse Giessereitechnischer Berufe, Verlag Handwerk und Technik.

[8] Wahyono Suprapto. (2011), Porositas Gas Pada Material Duralumin dalam Pengecoran Sistem Vakum, Disertasi FTMM-UI. 